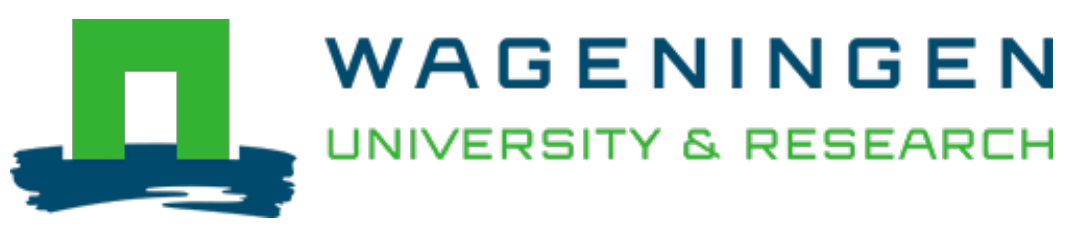

\title{
Conifer and broadleaved trees differ in branch allometry but maintain similar functional balances
}

\author{
Tree Physiology \\ Zhang, Lan; Chen, Yajun; Hao, Guangyou; Ma, Keping; Bongers, Frans et al \\ https://doi.org/10.1093/treephys/tpz139
}

This publication is made publicly available in the institutional repository of Wageningen University and Research, under the terms of article $25 \mathrm{fa}$ of the Dutch Copyright Act, also known as the Amendment Taverne. This has been done with explicit consent by the author.

Article 25 fa states that the author of a short scientific work funded either wholly or partially by Dutch public funds is entitled to make that work publicly available for no consideration following a reasonable period of time after the work was first published, provided that clear reference is made to the source of the first publication of the work.

This publication is distributed under The Association of Universities in the Netherlands (VSNU) 'Article $25 \mathrm{fa}$ implementation' project. In this project research outputs of researchers employed by Dutch Universities that comply with the legal requirements of Article $25 \mathrm{fa}$ of the Dutch Copyright Act are distributed online and free of cost or other barriers in institutional repositories. Research outputs are distributed six months after their first online publication in the original published version and with proper attribution to the source of the original publication.

You are permitted to download and use the publication for personal purposes. All rights remain with the author(s) and / or copyright owner(s) of this work. Any use of the publication or parts of it other than authorised under article $25 \mathrm{fa}$ of the Dutch Copyright act is prohibited. Wageningen University \& Research and the author(s) of this publication shall not be held responsible or liable for any damages resulting from your (re)use of this publication.

For questions regarding the public availability of this publication please contact openscience.library@wur.nl 


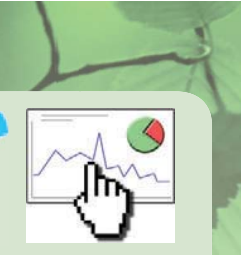

Tree Physiology 40, 511-519

doi:10.1093/treephys/tpz139

Research paper

\title{
Conifer and broadleaved trees differ in branch allometry but maintain similar functional balances
}

\author{
Lan Zhang ${ }^{1,2}$, Yajun Chen ${ }^{3,4,6}$, Guangyou Hao ${ }^{5}$, Keping $\mathrm{Ma}^{2,6}$, Frans Bongers ${ }^{1}$ and Frank J. Sterck ${ }^{1}$
}

${ }^{1}$ Forest Ecology and Forest Management Group, Wageningen University and Research Centre, PO Box 47, Wageningen, 6700 AA, The Netherlands; ${ }^{2}$ State Key Laboratory of Vegetation and Environmental Change, Institute of Botany, Chinese Academy of Sciences, 20 Nanxincun, Xiangshan, Beijing 100093, China; ${ }^{3}$ CAS Key Laboratory of Tropical Forest Ecology, Xishuangbanna Tropical Botanical Garden, Chinese Academy of Sciences, Menglun, Mengla, Yunnan 666303, China; ${ }^{4}$ Yuanjiang Savanna Ecosystem Research Station, Xishuangbanna Tropical Botanical Garden, Chinese Academy of Sciences, Pupiao Villiage Yuanjiang, Yunnan 666303 , China; ${ }^{5}$ CAS Key Laboratory of Forest Ecology and Management, Institute of Applied Ecology, Chinese Academy of Sciences, 72 Wenhua Road, Shenhe District Shenyang, Liaoning 110016, China; ${ }^{6}$ Corresponding authors Y. Chen (chenyj@xtbg.org.cn); K. Ma (kpma@ibcas.ac.cn)

Received September 18, 2019; accepted December 18, 2019; handling Editor Annikki Mäkelä

Conifers and broadleaved trees coexist in temperate forests and are expected to differ in partitioning strategies between leaf and stem. We compare functional balances between water loss and water supply, and between sugar production and sugar transport/storage, and associate these with xylem growth to better understand how they contribute to these life form strategies. We sampled canopy branches from 14 common species in a temperate forest in northeast China and measured xylem area, phloem area, ray area, ray percentage, dry wood density, xylem conductivity and mean xylem growth rate for branch stems, and the leaf area and specific leaf area for leaves, and calculated the leaf-specific conductivity. Conifers and broadleaved trees did not differ significantly in tissue areas, xylem growth rate and the relation between phloem area and leaf area. Conifers had higher xylem area but lower ray area relative to leaf area. For the same xylem conductivity, phloem area and ray parenchyma area did not differ between conifers and broadleaved trees. Xylem growth rate was similar relative to leaf area and phloem area. Our results indicate that conifers tend to develop more xylem area per leaf area and more tracheid area at the cost of ray parenchyma area, probably to compensate for the low water transport ability of tracheid-based xylem. The divergent strategies between conifers and broadleaved tree species in leaf area and xylem area partitioning probably lead to the convergence of partitioning between leaf area and phloem area. Consequently, conifers tend to consume rather than store carbon to achieve a similar xylem expansion per year as coexisting broadleaved trees.

Keywords: allometry, canopy, functional balance, wood anatomy, xylem growth.

\section{Introduction}

Plant strategies are proposed to be defined as 'grouping of similar or analogous genetic characteristics which recur widely among species or populations and cause them to exhibit similarities in ecology' (Grime 2006). Plant strategies are normally summarized across species to explain plant growth and survival, which ultimately determine the fate of species or plant communities. The partitioning of resources to plant organs has been seen as one of the most important plant strategies (Ostle et al. 2009, Franklin et al. 2012). Functional balance between leaf, stem and root (in both biomass and area) is one of the approaches to quantify resource partitioning to different plant organs (Enquist and Niklas 2002, Poorter et al. 2015, Mencuccini et al. 2019). As water loss through leaves and transport in xylem is essential to plant survival, the ratio between xylem cross-sectional area and leaf area (the Huber value) is often used to reflect the functional balance between water loss and supply (Whitehead et al. 1984). The relationship between

(C) The Author(s) 2020. Published by Oxford University Press. All rights reserved. For permissions, please e-mail: journals.permissions@oup.com 
the acquisition, transport and storage of carbohydrates is often ignored in studies, but this relationship is also important to reveal plant strategy (Zhang et al. 2016). In this paper, we study both water- and sugar-related functional balances, to better understand plant partitioning strategies, and discuss the consequences for plant growth.

Conifers and broadleaved trees differ fundamentally in morphology, anatomy and functioning (Bond 1989, Tyree and Ewers 1991, Becker et al. 1999) but coexist in many temperate forests (Schmitt et al. 2009). Broadleaved angiosperm trees are often deciduous in temperate forests and have specialized cells for water transport (vessels) and mechanical support (fibres) in the wood. Conifers with needle-like-stereotyped shape and size leaves use the same type of cells (tracheids) in their wood for water transport and support. Conifers have a less efficient transport system in the stem xylem and lower gas exchange rates in the leaves (Becker et al. 1999, Brodribb and Feild 2000, Brodribb et al. 2005), resulting in lower maximum growth rates in well lit, well-watered habitats compared with broadleaved trees (Waring 1983, Bond 1989, Waring et al. 2016). Meanwhile, conifers are expected to have less efficient sugar transport in phloem (Hölttä et al. 2009, Petit and Crivellaro 2014, Jyske and Hölttä 2015), though empirical data are scarce (Srivastava 1975, Thompson et al. 1979, Helfter et al. 2007, Liesche et al. 2015).

Trees compete with one another to display their leaves at favourable high light conditions in the upper canopy. Their leaves can achieve high gas exchange rates, but this comes with high demands for water supply within the xylem and for sugar transport in the phloem of the stem. While trees grow larger, they balance their increasing leaf area with increasing supporting xylem area (Duursma and Falster 2016, Kiorapostolou and Petit 2018) and with larger phloem area, though data for this are scarce (Giaquinta 1978, Nikinmaa et al. 2013). More indirectly, a relationship can be expected between leaf area and ray parenchyma area, which serves for storage of water and sugars (Holbrook, 1995, Borchert and Pockman 2005, Plavcová and Jansen 2015). Ray parenchyma is known to be lower in cross-sectional fraction in conifers than in broadleaved trees. (Morris et al. 2016), which is probably linked to a lower stem capacitance in conifers (Martínez-Cabrera et al. 2009, Fu et al. 2019). In this study, we explore functional relations between leaf area where carbon and water exchange occurs between plant and atmosphere versus xylem area, phloem area and ray parenchyma area as proxies for water transport, sugar transport and water and sugar storage, respectively. We will show how conifer trees and broadleaved trees organize their tissues in different ways, and thus have different partitioning strategies.

Our study compares branches of canopy trees of conifer and broadleaved tree species that coexist in a natural, temperate forest. We expect that conifers differ from broadleaved trees by having a larger xylem area for a given leaf area, which compensates for a lower xylem-specific conductivity (conductivity per sapwood area), less phloem area, ray parenchyma area and xylem conductivity for a given leaf area, and a lower phloem area and ray parenchyma area for a given xylem conductivity because their leaves produce assimilates at lower rates, and therefore, they have lower capacity required for transport and storage. Consequently, xylem growth rate is expected to be higher for the amount of leaf area and phloem area in broadleaved trees.

We focus on exposed branches in the upper canopy as (i) these branches act as major contributors of transpiration and carbon assimilation to the entire tree and (ii) it is feasible to control the tapering impacts of xylem and phloem on their related functionalities by standardizing branch length (Becker et al. 2000, Petit and Anfodillo 2009).

\section{Materials and methods}

\section{Study site}

The study was carried out from June to July, 2017, in Changbaishan Nature Reserve, Jilin Province, NE China $\left(41^{\circ} 15^{\prime}-42^{\circ} 35^{\prime} \mathrm{N}\right.$, $\left.127^{\circ} 15^{\prime}-129^{\circ} 00^{\prime} \mathrm{E}\right)$. The site is a typical evergreen conifer (except Larix) and deciduous broadleaf mixed forest (Zhou and Dai 2012). The site has an altitude of around $800 \mathrm{~m}$ and has a canopy crane installed with a height of $60 \mathrm{~m}$ and a radius of $30 \mathrm{~m}$. The climate is temperate continental climate affected by the monsoon with long and cold winters, and warm, rainy and short summers. Annual temperature is $3.6{ }^{\circ} \mathrm{C}$ and annual precipitation is around $700 \mathrm{~mm}$.

\section{Field work}

We sampled 14 common species that were in reach of the canopy crane or had canopies that were reachable by climbers (Table 1). We collected canopy branches from four evergreen and one deciduous conifer species, and nine broadleaved tree species (Table 1). For each species, three individuals (except Tilia mandshurica, for which only two individuals' canopies were accessible by the climber) were selected. From each individual tree, a 0.5-m-long sun-exposed canopy branch was cut, and the basal 10-cm branch segment was cut and preserved in Formalin-Aceto-Alcohol (FAA) solution for anatomical analysis. All leaves on the 0.5-m-long branch were collected into a Ziplock bag for leaf-trait measurements. The stem segment of the branch was taken at a fixed distance to apex $(0.5 \mathrm{~m})$ to control for the effects of tapering in xylem and phloem transport cells (Anfodillo et al. 2013, Petit and Crivellaro 2014).

In addition, branch samples in the canopy were collected to determine the specific conductivity of the stem: for this purpose, at least six branches were cut at 0.5-m length from the apex for conifers or ca two times of maximum vessel length for broadleaved trees for hydraulic measurements. All branches were immediately treated: (i) side twigs were cut off, but ca 
Table 1. Species list of sampled trees in Changbaishan forest. Their phenology and averaged diameter at breast height from sampled trees are given.

\begin{tabular}{|c|c|c|c|c|c|c|c|}
\hline Species name & Family & Phenology & $\mathrm{DBH}$ & $\mathrm{D}$ & Age & MVL & Sample method \\
\hline Abies nephrolepis (Trautv. ex Maxim.) Maxim. & Pinaceae & Evergreen & 21.2 & 0.67 & $4-8$ & - & Climber \\
\hline Picea koraiensis Nakai & Pinaceae & Evergreen & 39.6 & 0.69 & $3-5$ & - & Climber \\
\hline Pinus densiflora Siebold \& Zucc. & Pinaceae & Evergreen & 31.9 & 0.84 & $3-5$ & - & Climber \\
\hline Pinus koraiensis Siebold \& Zucc. & Pinaceae & Evergreen & 56.6 & 0.79 & $4-6$ & - & Crane \\
\hline Betula platyphylla Sukaczev & Betulaceae & Deciduous & 38.7 & 0.44 & $3-4$ & 0.19 & Climber \\
\hline Fraxinus mandshurica Rupr. & Oleaceae & Deciduous & 91.0 & 0.86 & $4-8$ & 0.86 & Crane \\
\hline Juglans mandshurica Maxim. & Juglandaceae & Deciduous & 26.2 & 1.10 & $2-3$ & 0.39 & Crane and climber \\
\hline Populus tremula var. davidiana (Dode) C.K.Schneid. & Salicaceae & Deciduous & 26.8 & 0.45 & $2-3$ & 0.58 & Climber \\
\hline Quercus mongolica Fisch. ex Ledeb. & Fagaceae & Deciduous & 72.3 & 0.82 & $4-7$ & 0.61 & Crane \\
\hline
\end{tabular}

Diameter at breast height $(\mathrm{DBH})(\mathrm{cm})$, averaged branch diameter $(\mathrm{D}, \mathrm{cm})$ of the branch segment (at $50 \mathrm{~cm}$ from the tip of canopy branch) and range of age (year) are given. Maximum vessel length (MVL, $m$ ) of broadleaved tree species is indicated. Species names are standardized by The Plant List (http://www.theplantlist.org).

10-cm base was left in order to avoid cavitation propagation to the main stem by cutting; (ii) fresh water was sprayed on the whole branch, and the cut ends were wrapped with Parafilm; and (iii) each branch was put into a black plastic bag and wrapped.

\section{Leaf-trait measurements}

All leaves from each branch of broadleaved species were scanned (CanoScan LiDE 220) and the total leaf area (LA, $\mathrm{cm}^{2}$ ) calculated using ImageJ software (v.1.44; developed by W. Rasband, National Institutes of Health, Bethesda, MD, USA). For conifers, ca one-tenth of their fresh needle leaves were scanned (CanoScan LiDE 220) and measured (ImageJ software, v.1.44). We doubled the scanned area of needle leaves as the measured leaf area (Waring 1983, Körner 1995). The total leaf area was estimated by the proportion of measured leaf weight to the total leaf weight. Leaves were then oven $(\mathrm{PH} 240 \mathrm{O})$ dried at $65^{\circ} \mathrm{C}$ for $48 \mathrm{~h}$ and weighed (Leaf dry mass, LD, g). Specific leaf area $\left(\mathrm{SLA}, \mathrm{cm}^{2} \mathrm{~g}^{-1}\right.$ ) was calculated as:

$$
S L A=L A / L D
$$

\section{Anatomical measurements}

Permanent cross-sections were made using the paraffin embedding method for further anatomical measurements. One 1- to 1.5-mm-thick branch piece was cut with a razor blade from each $10-\mathrm{cm}$ stem segment that was embedded in the FAA solution. These pieces were dehydrated with a series of 50-96-100\% ethanol. After this, they were infiltrated with limonene at air temperature and then with melted paraffin at $65^{\circ} \mathrm{C}$ in an oven (PH24OA). Afterwards, we embedded these pieces into paraffin blocks using a Leica EG1150H Paraffin Embedding Station (Leica Biosystems Nussloch GmbH, Nussloch, Germany). After the paraffin blocks got hard, we cut a 6- to 10- $\mu$ m-thick crosssection per piece using a Leica RM2235 rotary microtome (Leica Biosystems Nussloch $\mathrm{GmbH}$ ). Then, we removed the paraffin from the cross-sections with limonene and dehydrated the pieces again by $50-96-100 \%$ ethanol series. Following dehydration, all cross-sections were stained in a safranin/astra blue solution and fixed in Neutral Balsam. After the Neutral Balsam was air dried, photographs of entire cross-sections were taken with a digital camera (Nikon DS-Ri1) mounted on a microscope (Nikon ECLIPSE 80i) using Nikon Imaging Software, NIS Elements (Nikon, Tokyo, Japan). To obtain a photograph of the entire cross-section, sequential photographs were stitched using PTGUIPRO (v.9.1.8; New House Internet Services BV, Rotterdam, The Netherlands). Tissue areas of the pith, xylem and phloem in the cross-sections were measured firstly by ImageJ software (v.1.44). Then, ray parenchyma areas of cross-sections were measured using the pie-observe method describing in Zhang et al. (2016): we selected four pie-shaped areas in four directions of a cross-section along rays, including a ray along a side and excluding it on the other. For the phloem, we determined the area covered by rays, phloem fibres and sclereids. We subtracted the phloem ray, sclereids and fibre area from the total phloem area, resulting in the tissue that is important for axial phloem transport. This is referred to in the text as axial phloem area. Branch age was measured by counting rings in the stem cross-section. Finally, mean xylem growth rate was calculated by xylem area dividing by branch age.

\section{Hydraulic measurements}

We determined xylem-specific hydraulic conductivity $\left(K_{\mathrm{S}}\right.$, $\mathrm{kg} \mathrm{m}^{-1} \mathrm{~s}^{-1} \mathrm{MPa}^{-1}$ ) using a water flow meter system (Sperry et al. 1988). Branch samples were trimmed into ca $1.5 \times$ the 
length of the maximum vessel length (MVL) under water. The MVL was predetermined for each species (Table 1) by the air injection method as described in Ewers and Fisher (1989). The remaining branch segments were flushed with $10 \mathrm{mM}$ degassed $\mathrm{KCl}$ solution at $100-\mathrm{kPa}$ pressure for $1 \mathrm{~h}$ to reach a maximum flow rate. Afterwards, the upstream ends were connected to $\mathrm{KCl}$ solution with ca $5 \mathrm{kPa}$. The distal segment was connected to a pipette. A steady flow rate was obtained after ca 3- to 5-min equilibrium. The $K_{\mathrm{S}}$ was then calculated as:

$$
K_{\mathrm{S}}=F L /\left(\Delta P A_{S}\right),
$$

where $F\left(\mathrm{~kg} \mathrm{~s}^{-1}\right)$ is the water flow rate, $L$ is segment length $(\mathrm{m})$, $\Delta P$ is pressure difference between the two ends of the segment $(\mathrm{MPa})$ and $\mathrm{As}_{\mathrm{S}}\left(\mathrm{cm}^{2}\right)$ is the conducting sapwood area. Then, the xylem conductivity of $50-\mathrm{cm}$-branch segment was estimated by $K_{\mathrm{S}}$ multiplied by xylem area.

\section{Wood density measurements}

After hydraulic measurements, one 10-cm-long branch segment was cut and fresh volume $\left(\mathrm{V}, \mathrm{cm}^{-3}\right)$ was determined using the water displacement method. The branch segment was then dried in an oven (PH24OA) at $65^{\circ} \mathrm{C}$ for $48 \mathrm{~h}$ and weighed (DW, $\mathrm{g}$ ), and dry wood density (WD, $\mathrm{g} \mathrm{cm}^{-3}$ ) was calculated as:

$$
\mathrm{WD}=\mathrm{DW} / \mathrm{V}
$$

\section{Statistics}

Differences between broadleaved tree and conifer species in tissue sizes, xylem growth rate, xylem-specific conductivity and ray parenchyma percentage were tested using a linear mixed model with 41 individuals from 14 species. Life form was set as a fixed factor to test the mean differences between broadleaved tree and conifer species. Age was set as a fixed factor to control its effect, and species was set as a random factor to account for multiple observations within species.

We tested allometric trends using a linear mixed model as well. In the model, we compared areas of two tissues types (usually leaf area versus a stem tissue area), and tissue areas with xylem growth rate. We included life form as a fixed factor to examine the intercept difference between two life forms. Species was set as a random factor to account for multiple observations within species. All variables were $\log _{10}$ transformed.

All statistical tests were conducted using RStudio (Version 0.99.903) packed with R 3.3.3 (R Development Core Team 2016). Linear regressions were performed with the $I m$ function in the Ime4 package (Bates et al. 2007).

\section{Phylogeny}

To examine how plant traits may have been influenced by phylogeny, we constructed a phylogenetic tree using the program Phylomatic (http://phylodiversity.net/phylomatic, accessed 22
February 2019). We constructed a species-level tree with trait value being averaged within species. Phylogenetic conservatism in all traits was then analysed using Blomberg's $K$ statistic, which compares the observed signal in a trait to the signal under a Brownian motion model of trait evolution on a phylogeny (Blomberg et al. 2003). $K$ values closer to zero correspond to a random or convergent pattern of evolution, while $K$ values greater than 1 indicate strong phylogenetic signal and conservatism of traits. To examine possible coordinated divergences in water- and sugar-related traits, we analysed phylogenetic independent contrast values (PICs) using Pearson productmoment correlations (Zanne et al. 2010). Phylogenetic analyses were performed using RStudio (Version 0.99.903) packed with R 3.3.3 (R Development Core Team 2016) including packages APE (Paradis et al. 2004) and Picante (Webb et al. 2010).

\section{Results}

Conifers and broadleaved trees had a similar pith area, xylem area and phloem area in their canopy branches. Ray percentage, xylem-specific conductivity, leaf-specific conductivity and mean xylem growth rate did not significantly differ between conifers and broadleaved trees. Conifers had lower leaf area, specific leaf area and dry wood density (Table 2).

For all explored relationships, slopes were the same between the two life forms, and only the intercept varied or not, depending on the relationship. Xylem area, axial phloem area, ray parenchyma area and xylem conductivity increased with leaf area in both conifers and broadleaved trees (Figure 1). Conifers had a higher intercept in the linear relation between xylem area and leaf area, but a lower intercept in the linear relation between ray parenchyma area and xylem conductivity with leaf area. Axial phloem area and ray parenchyma area increased with xylem conductivity in both conifers and broadleaved trees (Figure 2). Mean xylem growth rate increased with leaf area and axial phloem area (Figure 3).

Phylogenetic signal $K$ values were $<1$ for pith area, xylem area, phloem area, axial phloem area, ray area, ray percentage, leaf area, xylem-specific hydraulic conductivity, xylem growth rate and xylem conductivity, with corresponding $P$-values $>0.05$ (Table S2 available as Supplementary Data at Tree Physiology Online). All relations in Figures 1-3 were significantly correlated when considering phylogenetic divergences, using independent contrasts (Table S3 available as Supplementary Data at Tree Physiology Online).

\section{Discussion}

In this study, we compared canopy branches between conifers and broadleaved trees in the same natural temperate forest. We studied their partitioning strategies through functional balances within branches by quantifying allometric relationships between 
Table 2. Canopy branch traits of conifers and broadleaved tree species in Changbaishan forest.

\begin{tabular}{|c|c|c|c|c|c|c|c|c|c|c|c|}
\hline Variables & Unit & \multicolumn{4}{|l|}{ Means } & \multicolumn{2}{|l|}{ Life form } & \multicolumn{2}{|l|}{ Age } & \multicolumn{2}{|c|}{ Age* Life form } \\
\hline Pith area & $\mathrm{cm}^{2}$ & 0.019 & 0.0053 & 0.026 & 0.0080 & 0.124 & 0.902 & -1.661 & 0.108 & -0.203 & 0.841 \\
\hline Xylem area & $\mathrm{cm}^{2}$ & 0.29 & 0.028 & 0.27 & 0.031 & 0.050 & 0.960 & 0.458 & 0.650 & -0.448 & 0.657 \\
\hline Phloem area & $\mathrm{cm}^{2}$ & 0.10 & 0.011 & 0.13 & 0.018 & 0.601 & 0.552 & 1.114 & 0.275 & -0.652 & 0.520 \\
\hline Ray percentage & $\%$ & 5.03 & 0.27 & 12.46 & 0.59 & 2.014 & 0.051 & -0.239 & 0.813 & 1.251 & 0.220 \\
\hline Xylem growth rate & $\mathrm{cm}^{2}$ year $^{-1}$ & 0.066 & 0.0093 & 0.072 & 0.013 & 0.217 & 0.830 & -2.032 & 0.052 & -0.506 & 0.617 \\
\hline Leaf area & $\mathrm{cm}^{2}$ & 1495.25 & 127.85 & 2666.20 & 469.82 & 2.163 & 0.039 & 1.458 & 0.157 & -2.292 & 0.030 \\
\hline LSC & $10^{-4} \mathrm{~kg} \mathrm{~m}^{-1} \mathrm{~s}^{-1} \mathrm{MPa}^{-1}$ & 1.66 & 0.28 & 4.19 & 0.64 & -0.346 & 0.731 & -1.485 & 0.147 & 1.594 & 0.120 \\
\hline SLA & $\mathrm{cm}^{2} \mathrm{~g}^{-1}$ & 60.29 & 9.75 & 137.74 & 11.72 & 2.243 & 0.031 & 0.038 & 0.970 & 0.140 & 0.890 \\
\hline
\end{tabular}

Absolute pith area, xylem area, phloem area, ray percentage, xylem-specific conductivity $\left(K_{\mathrm{S}}\right)$, wood density, xylem growth rate, leaf area, leaf-specific conductivity (LSC) and specific leaf area (SLA) for conifers $(n=5)$ and broadleaved tree species $(n=9)$ are shown. Group differences were tested with a linear mixed model using 41 individuals from 14 species. Branch age (years) was set as a fixed factor and species was set as a random factor to account for multiple observations within species. Their interactions were also included in statistics. All variables were log 10 transformed except ray percentage and wood density. Means of each variable and their SE were given. $\mathrm{P}<0.05$ was indicated by bold letters.
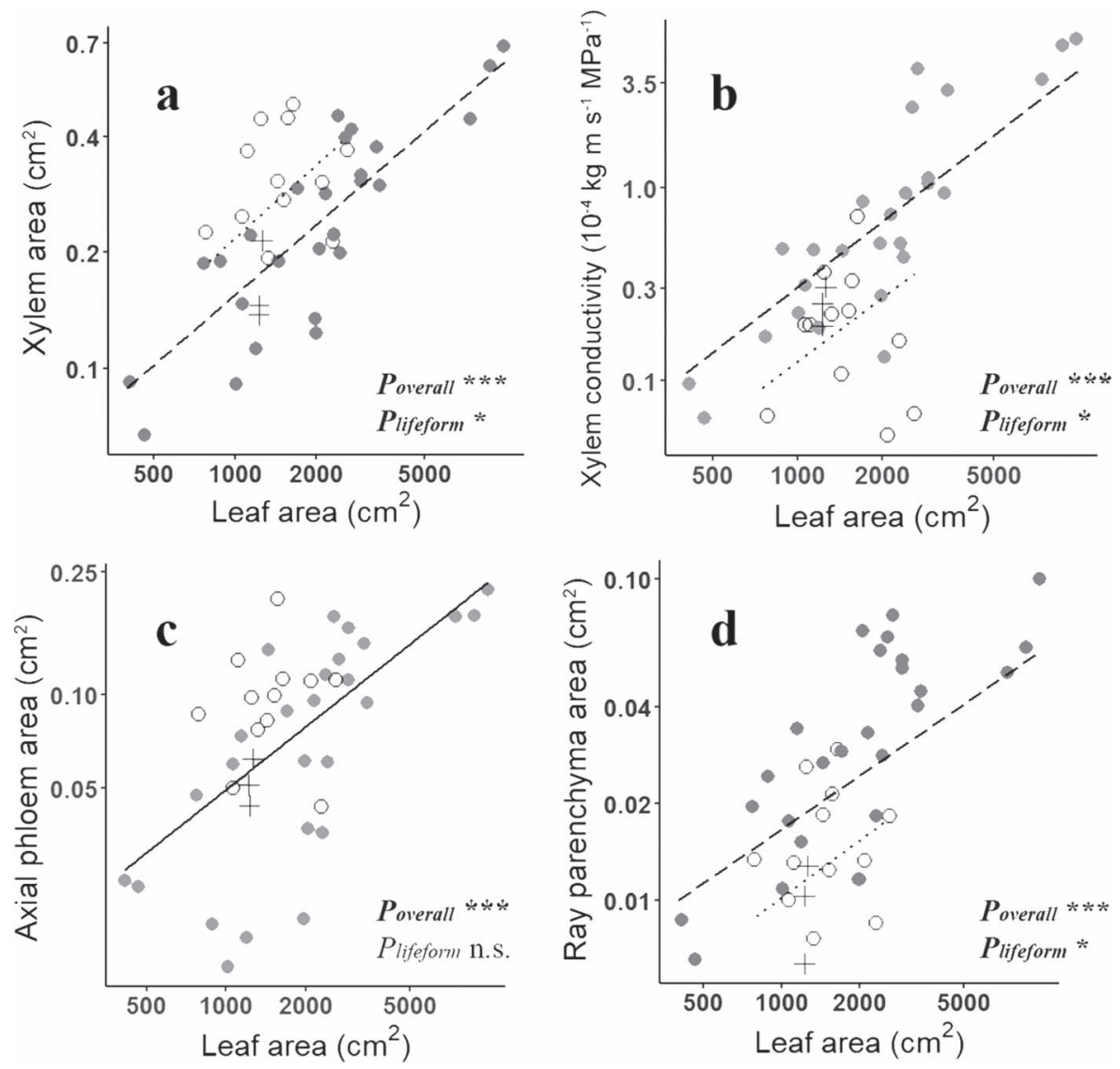

Figure 1. Relations of leaf area with (a) xylem area, (b) xylem conductivity, (c) axial phloem area and (d) ray area for temperate tree species in Changbaishan forest. Grey dots represent broadleaved trees and open dots represent conifers; the deciduous conifer Larix is represented by crosses. Overall significant effects are indicated by solid lines. Dashed lines represent broadleaved trees and dotted lines represent conifers. ${ }^{*} P<0.05$, *** $P<0.001 ;$ n.s., not significant. 


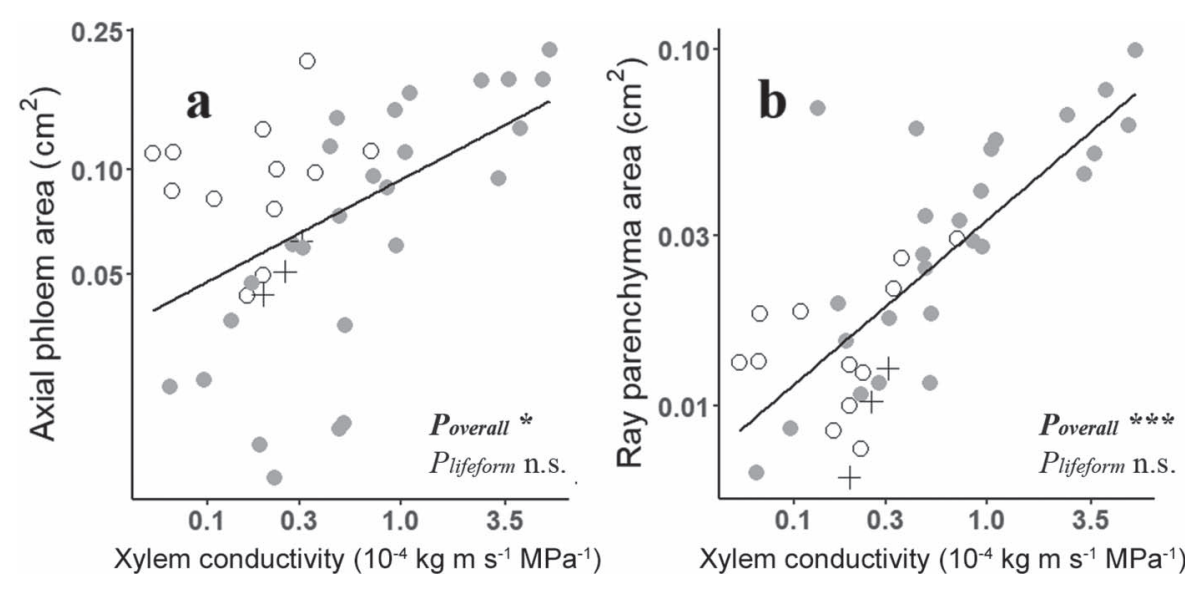

Figure 2. Relations of xylem conductivity with (a) axial phloem area and (b) ray area for temperate tree species in Changbaishan forest. Grey dots represent broadleaved trees and open dots represent conifers; the deciduous conifer Larix is represented by crosses. Significant correlations effects are indicated by solid lines. ${ }^{*} P<0.05,{ }^{* * *} P<0.001$. n.s., not significant.
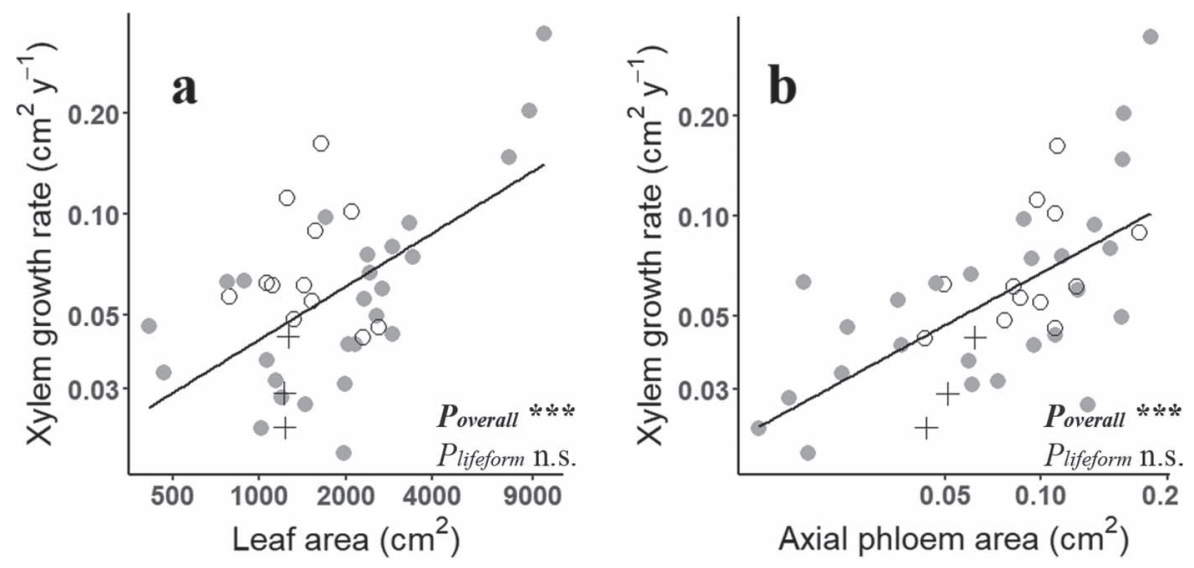

Figure 3. Relations of (a) leaf area and (b) axial phloem area with xylem growth rate for temperate tree species in Changbaishan forest. Grey dots represent broadleaved trees and open dots represent conifers; the deciduous conifer Larix is represented by crosses. Significant correlations are indicated by solid lines. ${ }^{* * *}$ means $P<0.001$. n.s. not significant.

the leaf area and stem tissue areas. These balances represent the coordination of water loss in the leaves versus water transport in the xylem and storage in the ray parenchyma in the stem, and the coordination between carbon gain in the leaves versus sugar transport in the phloem and storage in the ray parenchyma. In addition, we related these tissue sizes to growth for both conifers and broadleaved trees. In phylogenetic analysis, only ray percentage was phylogenetically controlled (Table S2 available as Supplementary Data at Tree Physiology Online). All the allometric relationships arose repeatedly and widely throughout the evolutionary history (Table S3 available as Supplementary Data at Tree Physiology Online) (Zheng et al. 2019).

\section{Partitioning in leaf area and xylem area in conifers and broadleaved trees}

As expected, conifers had more xylem area for the amount of supported leaf area (Figure 1a). This is consistent with results from surveys in the temperate zone (Brouat et al. 1998, Becker 2000) and a scaling study across Europe (Petit and
Kiorapostolou 2018) comparing evergreen conifers with deciduous broadleaved trees. Given that conifers have a lower xylem conductivity (Figure 1b), this confirms that conifers compensate their less efficient water conducting system by producing more xylem for a given leaf area. Accordingly, we observed that conifers and broadleaved tree species did not differ in leafspecific conductivity (Table 2).

However, no such allometric differences were observed when comparing (evergreen) conifers with evergreen angiosperms first year shoots in temperate and Mediterranean areas (Brouat et al. 1998, Becker 2000, Lusk et al. 2007). This is remarkable because evergreen angiosperms tend to have a higher branch hydraulic conductivity than coexisting evergreen conifers (Lusk et al. 2007). These studies however focused on saplings or very small branches (diameter $<7.5 \mathrm{~mm}$ ) with lower water supply demands. Possibly, the high light levels and high transpiration demands for the exposed branches of our studied canopy trees resulted in the divergence between conifers and broadleaved trees (Thomas and Winner 2002), whereas such divergence is 
less clear for saplings in the forest understory (Meinzer et al. 1999, Mencuccini and Comstock 1999, Brodribb and Feild 2000).

\section{Partitioning in leaf area, phloem area and ray parenchyma} area in conifers and broadleaved trees

Conifer and broadleaved tree species did not differ in axial phloem area for a given leaf area (Figure 1c). This indicates that, though broadleaved trees in general have a higher carbon gain rate per leaf area, they might build up a more efficient phloem transport system to move sugars to carbon sinks elsewhere in trees rather than enlarging axial phloem area. This would be consistent with Dannoura et al. (2011), who found a higher velocity of carbon transfer in oak and beech compared with pine in a temperate forest. Moreover, this is also supported by Hölttä et al. (2014) and Jyske and Hölttä (2015), who showed that the xylem hydraulic efficiency is closely coupled to phloem transport efficiency, which can be expected from the coordination of xylem conduit sizes and phloem cell sizes from the same cambium (Petit and Crivellaro 2014). Yet, we lack an empirical test whether broadleaved trees have a higher phloem specific conductivity to compensate for a similar phloem area as conifers.

As expected, conifers have a lower ray percentage (Table 2) and ray area per unit leaf area than broadleaved trees (Figure 1d). This is in line with Morris et al. (2016), who found lower ray percentage in conifers, and in line with the strong phylogenetic effect that we found for traits related to ray parenchyma. These results suggest that broadleaved trees have a higher water and sugar storage capacity than coexisting conifers. One reason for evergreen conifers to have lower storage capacity could be their longer leaf life span (Reich et al. 1995, Lusk 2001), which may lower the carbon storage requirements for crown maintenance during winters. In contrast, deciduous broadleaved trees may require a high storage capacity for carbon to survive winter and renew leaves every spring (Epron et al. 2012). However, the conifer species Larix is also deciduous, and did not have a higher ray area per leaf area than the other conifer species. As conifers' xylem is mainly built up with tracheids and ray parenchyma cells, tracheid area is directly suppressed by larger ray parenchyma area. This can lower the water transport ability in xylem. However, the vessel area of broadleaved trees is independent of ray area (Fortunel et al. 2014). Thus, conifers tend to maximize water transport ability by minimizing the occupation of ray parenchyma to meet water transport demand.

\section{Ray and phloem development with xylem growth rate}

Contrary to our expectation, conifers and broadleaved trees tend to achieve similar xylem growth rates when scaled with leaf area or phloem area (Figure 3). Though it is widely known that leaf area positively relates with stem growth (Waring et al. 1980, Waring 1983), and that phloem has important effects on plant growth (Savage et al. 2016), the allocation comparisons on canopy branches between coexisting conifers and broadleaved trees have not yet been done. The convergent xylem growth rate reveals that conifers may alter other traits to compensate the low carbon fixation rate in leaves and slow mass flow in phloem (Epron et al. 2012, Liesche and Schulz 2018), to achieve a similar xylem growth rate to that of broadleaved trees. In addition, xylem growth rate is not phylogenetically regulated (Table S2 available as Supplementary Data at Tree Physiology Online), suggesting that it indeed can be affected by other traits. Producing low-cost wood (lower wood density; Table 2) could be one of the strategies across conifers to overcome these disadvantages. Besides, the similar allocation of phloem area and ray area relative to the amount of xylem conductivity (Figure 2) indicates that conifers and broadleaved trees may actually have comparable allocation of sugars into transport and storage area, leading to a similar xylem growth rate.

\section{Conclusion}

Most of our expectations on the allocation differences between conifers and broadleaved trees were not supported by our data for the studied temperate forest in NE China. Conifers maintain functional water balance between stem and leaves by compensating their low hydraulic conductivity with a wider xylem area. Broadleaved trees maintain functional carbon balance not by creating a larger phloem area per leaf area, but possibly by having more or larger conductive cells in phloem; this hypothesis still needs to be tested. The large ray area in broadleaved trees may hint to their role in carbon storage during winter, while the low ray area in conifers may be a compromise for maximizing water transport. These partitioning strategies may lead to a similar xylem growth rate of canopy branches between conifers and broadleaved trees. In summary, conifers tend to facilitate carbon gain (produce more xylem area per leaf area) and consume carbon for xylem development rather than preserve them in storage tissue as broadleaved trees do. We suggest that the allocation between leaf area (carbon gain) and phloem (carbon transport) and ray (carbon and water storage) area could be important indicators in understanding adaptation of different life forms or phenology. More studies are required to draw firm conclusions on this.

\section{Supplementary Data}

Supplementary Data for this article are available at Tree Physiology Online.

\section{Acknowledgments}

We thank Alan Crivellaro, Padova University and Ute SassKlaassen, Wageningen University, for advice on anatomical 
observation and methods such as sample preparation and tissue recognition of cross-sections. We thank Song Lv, Jia Zhang and Guiguo Huo for field assistance, and the anatomical lab of Institute of Botany, Chinese Academy of Sciences for providing equipment to make cross-sections of branch samples. We thank the Changbaishan Station for Forest Ecosystem Studies, and Guanhua Dai, Lufu Zhao and Libao Wang for assistance in the sample collection.

\section{Conflicts of Interests}

None declared.

\section{Funding}

This study was financially supported by the Stichting Het Kronendak Canopy Grant, project 16-007; Koninklijke Nederlandse Akademie van Wetenschappen (KNAW) Chinese Exchange Program, project 530-5CDP20; the Stichting Fonds Landbouw Export Bureau 1916/1918 (LEB foundation), project 2017-003C and the KNAW Fonds Ecologie, project Eco/1747; the National Natural Science Foundation of China, project 41861144016, 31570406 and 31722013; the Youth Innovation Promotion Association, project 2016351; the 'Light of West China' Program of CAS, CAS 135 program, project 2017XTBG-T01 and 2017XTBG-FO1; and Yunnan Provincial Science and Technology Department, project 2018HB068.

\section{References}

Anfodillo T, Petit G, Crivellaro A (2013) Axial conduit widening in woody species: a still neglected anatomical pattern. IAWA J 34:352.

Bates D, Sarkar D, Bates MD, Matrix L (2007) The Ime4 package. R package version 2:74 ((March, 2019, date last accessed)).

Becker P (2000) Competition in the regeneration niche between conifers and angiosperms: Bond's slow seedling hypothesis. Funct Ecol 14:401-412.

Becker P, Tyree MT, Tsuda M (1999) Hydraulic conductances of angiosperms versus conifers: similar transport sufficiency at the whole-plant level. Tree Physiol 19:445-452.

Becker P, Gribben RJ, Lim CM (2000) Tapered conduits can buffer hydraulic conductance from path-length effects. Tree Physiol 20: 965-967.

Blomberg SP, Garland JRT, Ives AR (2003) Testing for phylogenetic signal in comparative data: behavioral traits are more labile. Evolution 57:717-745

Bond WJ (1989) The tortoise and the hare: ecology of angiosperm dominance and gymnosperm persistence. Biol J Linn Soc 36: 227-249.

Borchert R, Pockman WT (2005) Water storage capacitance and xylem tension in isolated branches of temperate and tropical trees. Tree Physiol 25:457-466.

Brodribb TJ, Feild TS (2000) Stem hydraulic supply is linked to leaf photosynthetic capacity: evidence from New Caledonian and Tasmanian rainforests. Plant Cell Environ 23:1381-1388.

Brodribb TJ, Holbrook NM, Zwieniecki MA, Palma B (2005) Leaf hydraulic capacity in ferns, conifers and angiosperms: impacts on photosynthetic maxima. New Phytol 165:839-846.
Brouat C, Gibernau M, Amsellem L, McKey D (1998) Corner's rules revisited: ontogenetic and interspecific patterns in leaf-stem allometry. New Phytol 139:459-470.

Dannoura M, Maillard P, Fresneau C et al. (2011) In situ assessment of the velocity of carbon transfer by tracing ${ }^{13} \mathrm{C}$ in trunk $\mathrm{CO}_{2}$ efflux after pulse labelling: variations among tree species and seasons. New Phytol 190:181-192.

Duursma RA, Falster DS (2016) Leaf mass per area, not total leaf area, drives differences in above-ground biomass distribution among woody plant functional types. New Phytol 212:368-376.

Enquist BJ, Niklas KJ (2002) Global allocation rules for patterns of biomass partitioning in seed plants. Sci 295:1517-1520.

Epron D, Bahn M, Derrien D et al. (2012) Pulse-labelling trees to study carbon allocation dynamics: a review of methods, current knowledge and future prospects. Tree Physiol 32:776-798.

Ewers FW, Fisher JB (1989) Techniques for measuring vessel lengths and diameters in stems of woody plants. Am J Bot 76: 645-656.

Fortunel C, Ruelle J, Beauchêne J, Fine PV, Baraloto C (2014) Wood specific gravity and anatomy of branches and roots in 113 Amazonian rainforest tree species across environmental gradients. New Phytol 202:79-94.

Franklin O, Johansson J, Dewar RC, Dieckmann U, McMurtrie RE, Brännström $\AA$, Dybzinski R (2012) Modeling carbon allocation in trees: a search for principles. Tree Physiol 32:648-666.

Fu X, Meinzer FC, Woodruff DR, Liu Y-Y, Smith DD, McCulloh KA, Howard AR (2019) Coordination and trade-offs between leaf and stem hydraulic traits and stomatal regulation along a spectrum of isohydry to anisohydry. Plant Cell Environ 42: 2245-2258.

Giaquinta R (1978) Source and sink leaf metabolism in relation to phloem translocation: carbon partitioning and enzymology. Plant Physiol 61:380-385.

Grime JP (2006) Plant strategies, vegetation processes, and ecosystem properties. John Wiley \& Sons, New Jersey, USA.

Helfter C, Shephard JD, Martínez-Vilalta J, Mencuccini M, Hand DP (2007) A noninvasive optical system for the measurement of xylem and phloem sap flow in woody plants of small stem size. Tree Physiol 27:169-179.

Holbrook M, N. (1995) Stem Water Storage. In: Gartner BL (ed) Plant stems Academic Press, San Diego, CA, pp 151-174.

Hölttä T, Mencuccini M, Nikinmaa E (2009) Linking phloem function to structure: analysis with a coupled xylem-phloem transport model. J Theor Biol 259:325-337.

Hölttä T, Mencuccini M, Nikinmaa E (2014) Ecophysiological aspects of phloem transport in trees. In: Tausz M, Grulke N (eds) Trees in a changing environment: ecophysiology, adaptation, and future survival. Springer, Dordrecht, pp 25-36.

Jyske T, Hölttä T (2015) Comparison of phloem and xylem hydraulic architecture in Picea abies stems. New Phytol 205:102-115.

Kiorapostolou N, Petit G (2018) Similarities and differences in the balances between leaf, xylem and phloem structures in Fraxinus ornus along an environmental gradient. Tree Physiol 39:234-242.

Körner C (1995) Leaf diffusive conductances in the major vegetation types of the globe. In: Schulze E-D, Caldwell MM (eds) Ecophysiology of photosynthesis. Springer Berlin Heidelberg, Berlin, Heidelberg, pp 463-490.

Liesche J, Schulz A (2018) Phloem transport in gymnosperms: a question of pressure and resistance. Curr Opin Plant Biol 43:36-42.

Liesche J, Windt C, Bohr T, Schulz A, Jensen KH (2015) Slower phloem transport in gymnosperm trees can be attributed to higher sieve element resistance. Tree Physiol 35:376-386.

Lusk CH (2001) Leaf life spans of some conifers of the temperate forests of South America. Rev Chil Hist Nat 74:711-718. 
Lusk CH, Jiménez-Castillo M, Salazar-Ortega N (2007) Evidence that branches of evergreen angiosperm and coniferous trees differ in hydraulic conductance but not in Huber values. Can J Bot 85: 141-147.

Martínez-Cabrera HI, Jones CS, Espino S, Schenk HJ (2009) Wood anatomy and wood density in shrubs: responses to varying aridity along transcontinental transects. Am J Bot 96:1388-1398.

Meinzer FC, Goldstein G, Franco A, Bustamante M, Igler E, Jackson $P$, Caldas L, Rundel P (1999) Atmospheric and hydraulic limitations on transpiration in Brazilian Cerrado woody plant. Funct Ecol 13: 273-282.

Mencuccini M, Comstock J (1999) Variability in hydraulic architecture and gas exchange of common bean (Phaseolus vulgaris) cultivars under well-watered conditions: Interactions with leaf size. Aus J Plant Physiol 26:115-124.

Mencuccini M, Rosas T, Rowland L et al. (2019) Leaf economics and plant hydraulics drive leaf : wood area ratios. New Phytol; 224: 15441556.

Morris H, Plavcová L, Cvecko P et al. (2016) A global analysis of parenchyma tissue fractions in secondary xylem of seed plants. New Phytol 209:1553-1565.

Nikinmaa E, HoLtta T, Hari P, Kolari P, MAKelA A, Sevanto S, Vesala $T$ (2013) Assimilate transport in phloem sets conditions for leaf gas exchange. Plant Cell Environ 36:655-669.

Ostle NJ, Smith P, Fisher R et al. (2009) Integrating plant-soil interactions into global carbon cycle models. J Ecol 97:851-863.

Paradis E, Claude J, Strimmer K (2004) APE: analyses of phylogenetics and evolution in R language. Bioinformatics 20:289-290.

Petit G, Anfodillo T (2009) Plant physiology in theory and practice: an analysis of the WBE model for vascular plants. J Theor Biol 259: $1-4$.

Petit G, Crivellaro A (2014) Comparative axial widening of phloem and xylem conduits in small woody plants. Trees 28:915-921.

Petit G, Kiorapostolou N (2018) Similarities and differences in the balances between leaf, xylem and phloem structures in Fraxinus ornus along an environmental gradient. Tree Physiol 39:234-242.

Plavcová L, Jansen S (2015) The role of xylem parenchyma in the storage and utilization of nonstructural carbohydrates. In: Hacke $U$ (ed) Functional and ecological xylem anatomy. Springer International Publishing, Cham, pp 209-234.

Poorter H, Jagodzinski AM, Ruiz-Peinado R et al. (2015) How does biomass distribution change with size and differ among species? An analysis for 1200 plant species from five continents. New Phytol 208:736-749.

Reich P, Koike TT, Gower S, Schoettle A (1995) Causes and consequences of variation in conifer leaf life-span. Physiol Ecol 225-254.

Savage JA, Clearwater MJ, Haines DF, Klein T, Mencuccini M, Sevanto S, Turgeon R, Zhang C (2016) Allocation, stress tolerance and carbon transport in plants: how does phloem physiology affect plant ecology? Plant Cell Environ 39:709-725.
Schmitt CB, Belokurov A, Besançon C et al. (2009) Global ecological forest classification and forest protected area gap analysis. Analyses and recommendations in view of the $10 \%$ target for forest protection under the Convention on Biological Diversity (CBD). Freiburg University Press, Freiburg, Germany.

Sperry JS, Donnelly JR, Tyree MT (1988) A method for measuring hydraulic conductivity and embolism in xylem. Plant Cell Environ 11: 35-40.

Srivastava LM (1975) Structure and differentiation of sieve elements in angiosperms and gymnosperms. In: Aronoff S, Dainty J, Gorham PR, Srivastava LM, Swanson CA (eds) Phloem transport. Springer, Boston, MA, pp 33-78.

Thomas SC, Winner WE (2002) Photosynthetic differences between saplings and adult trees: an integration of field results by metaanalysis. Tree Physiol 22:117-127.

Thompson RG, Fensom DS, Anderson RR, Drouin R, Leiper W (1979) Translocation of 11C from leaves of Helianthus, Heracleum, Nymphoides, Ipomoea, Tropaeolum, Zea, Fraxinus, Ulmus, Picea, and Pinus: comparative shapes and some fine structure profiles. Can J Bot 57:845-863.

Tyree MT, Ewers FW (1991) The hydraulic architecture of trees and other woody plants. New Phytol 119:345-360.

Waring R, Landsberg J, Linder S (2016) Tamm review: insights gained from light use and leaf growth efficiency indices. For Ecol Manage 379:232-242.

Waring $\mathrm{RH}$ (1983) Estimating forest growth and efficiency in relation to canopy leaf area. In: Macfadyen A, Ford ED (eds) Advances in Ecological Research. Academic Press, San Diego, USA. pp 327-354.

Waring $\mathrm{RH}$, Thies WG, Muscato D (1980) Stem growth per unit of leaf area: a measure of tree vigor. For Sci 26:112-117.

Webb CO, Ackerly DD, Morlon H, Helmus MR, Cowan PD, Blomberg SP, Kembel SW, Cornwell WK (2010) Picante: R tools for integrating phylogenies and ecology. Bioinformatics 26:1463-1464.

Whitehead D, Edwards WRN, Jarvis PG (1984) Conducting sapwood area, foliage area, and permeability in mature trees of Picea sitchensis and Pinus contorta. Can J For Res 14:940-947.

Zanne AE, Westoby M, Falster DS, Ackerly DD, Loarie SR, Arnold SE, Coomes DA (2010) Angiosperm wood structure: global patterns in vessel anatomy and their relation to wood density and potential conductivity. Am J Bot 97:207-215.

Zhang L, Copini P, Weemstra M, Sterck FJ (2016) Functional ratios among leaf, xylem and phloem areas in branches change with shade tolerance, but not with local light conditions, across temperate tree species. New Phytol 209:1566-1575.

Zheng J, Zhao X, Morris H, Jansen S (2019) Phylogeny best explains latitudinal patterns of xylem tissue fractions for woody angiosperm species across China. Front Plant Sci 10. doi: 10.3389/fpls.2019.00556.

Zhou LW, Dai YC (2012) Recognizing ecological patterns of wooddecaying polypores on gymnosperm and angiosperm trees in northeast China. Fungal Ecol 5:230-235. 